\title{
Continental-scale variation in otolith geochemistry of juvenile American shad (Alosa sapidissima)
}

\author{
Benjamin D. Walther and Simon R. Thorrold
}

\begin{abstract}
We assembled a comprehensive atlas of geochemical signatures in juvenile American shad (Alosa sapidissima) to discriminate natal river origins on a large spatial scale and at a high spatial resolution. Otoliths and (or) water samples were collected from 20 major spawning rivers from Florida to Quebec and were analyzed for elemental (Mg:Ca, Mn:Ca, $\mathrm{Sr}: \mathrm{Ca}$, and $\mathrm{Ba}: \mathrm{Ca})$ and isotope $\left({ }^{87} \mathrm{Sr}:{ }^{86} \mathrm{Sr}\right.$ and $\left.\delta^{18} \mathrm{O}\right)$ ratios. We examined correlations between water chemistry and otolith composition for five rivers where both were sampled. While $\mathrm{Sr}: \mathrm{Ca}, \mathrm{Ba}: \mathrm{Ca},{ }^{87} \mathrm{Sr}:{ }^{86} \mathrm{Sr}$, and $\delta^{18} \mathrm{O}$ values in otoliths reflected those ratios in ambient waters, $\mathrm{Mg}: \mathrm{Ca}$ and $\mathrm{Mn}: \mathrm{Ca}$ ratios in otoliths varied independently of water chemistry. Geochemical signatures were highly distinct among rivers, with an average classification accuracy of $93 \%$ using only those variables where otolith values were accurately predicted from water chemistry data. The study represents the largest assembled database of otolith signatures from the entire native range of a species, encompassing approximately $2700 \mathrm{~km}$ of coastline and 19 degrees of latitude and including all major extant spawning populations. This database will allow reliable estimates of natal origins of migrating ocean-phase American shad from the 2004 annual cohort in the future.
\end{abstract}

Résumé : Nous avons compilé un vaste atlas des signatures géochimiques des jeunes aloses savoureuses (Alosa sapidissima) afin de pouvoir reconnaître leur rivière d'origine à la naissance sur une grande échelle géographique et à une forte résolution spatiale. Nous avons récolté des otolithes et (ou) des échantillons d'eau dans 20 rivières importantes pour la reproduction de la Floride au Québec et nous avons mesuré les rapports des éléments ( $\mathrm{Mg}: \mathrm{Ca}, \mathrm{Mn}: \mathrm{Ca}, \mathrm{Sr}: \mathrm{Ca}$ et $\mathrm{Ba}: \mathrm{Ca})$ et des isotopes $\left({ }^{87} \mathrm{Sr}:{ }^{86} \mathrm{Sr}\right.$ et $\left.\delta^{18} \mathrm{O}\right)$. Nous avons examiné les corrélations entre la chimie de l'eau et la composition des otolithes dans cinq rivières où les deux ont été échantillonnées. Alors que les valeurs de $\mathrm{Sr}: \mathrm{Ca}, \mathrm{Ba}: \mathrm{Ca},{ }^{87} \mathrm{Sr}:{ }^{86} \mathrm{Sr}$ et $\delta^{18} \mathrm{O}$ dans les otolithes reflètent les rapports mesurés dans les eaux ambiantes, les rapports $\mathrm{Mg}: \mathrm{Ca}$ et $\mathrm{Mn}: \mathrm{Ca}$ dans les otolithes varient indépendamment de la chimie de l'eau. Les signatures géochimiques sont très distinctes d'une rivière à l'autre et la justesse moyenne des classifications est de $93 \%$ lorsqu' on utilise seulement les variables dont la teneur dans les otolithes peut être prédite avec précision à partir des données de chimie des eaux. Notre étude comprend la plus grande banque de signatures d'otolithes provenant de l'ensemble de l'aire de répartition indigène d'une espèce, couvrant environ 2700 km de côtes et 19 degrés de latitude et incluant toutes les principales populations reproductrices actuelles. Cette banque de données permettra dans le futur des déterminations fiables de la rivière d'origine à la naissance des aloses de la cohorte annuelle de 2004 en migration durant leur phase océanique.

[Traduit par la Rédaction]

\section{Introduction}

The movements of diadromous fishes during oceanic residency are often poorly understood (Metcalfe et al. 2002; McDowall 2003). Most anadromous species leave their natal rivers to enter marine waters relatively early in their life cycle at a size that is difficult to catch and physically mark in sufficient numbers without inducing major handling effects. Fish may subsequently travel thousands of kilometres before returning to freshwater spawning locations (Dadswell et al. 1987; Quinn and Leggett 1987). Groups of migrating fish collected in oceanic environments often, then, comprise individuals from numerous source populations, though the stock compositions of these mixed groups are generally unknown. Our inability to determine natal origins remains a major problem for determining stock-specific exploitation rates in ocean-intercept fisheries and more generally in attempts to link climate variability with changes in the distribution, growth, and mortality of anadromous fish populations during the ocean phase of their life history.

While conventional tagging studies may be logistically difficult in highly dispersive marine systems, substantial

Received 10 December 2007. Accepted 26 August 2008. Published on the NRC Research Press Web site at cjfas.nrc.ca on 26 November 2008.

J20315

B.D. Walther ${ }^{1,2}$ and S.R. Thorrold. Biology Department MS 50, Woods Hole Oceanographic Institution, Woods Hole, MA 02543, USA.

${ }^{1}$ Corresponding author (e-mail: benjamin.walther@anu.edu.au).

${ }^{2}$ Present address: Australian Research Council (ARC) Centre of Excellence for Coral Reef Studies, Australian National University,

Research School of Earth Sciences, Canberra, ACT 0200, Australia. 
progress has been made using natural markers of population affinities (Thorrold et al. 2002). Although rarely as unequivocal as artificial labels, natural tags avoid handling issues and, because all individuals from a population are marked, may be particularly useful when recapture rates are expected to be low. For instance, population genetic markers, including allozyme and DNA loci, have been used for mixed stock analyses of anadromous fishes collected in ocean-intercept fisheries (Brodziak et al. 1992; Brown et al. 1999). More recently, geochemical signatures in fish ear bones (otoliths) have been successfully used to determine natal origins of migratory fishes (Campana and Thorrold 2001). Otoliths are paired aragonitic structures in the inner ears of bony fishes and grow by the continuous accretion of metabolically inert material (Campana and Nielson 1985; Campana 1999). The composition of accreted material reflects the chemistry, temperature, and salinity of the ambient water in which the fish resided (Bath et al. 2000; Walther and Thorrold 2006). Thus, otoliths effectively record variations in environmental parameters over the lifespan of the fish. Fish that are spawned in chemically distinct habitats record these proxies of natal origin in the core region of their otoliths. Each individual from these habitats is indelibly tagged for life, making reconstructions of movement patterns possible (Thorrold et al. 2001).

American shad (Alosa sapidissima) are anadromous alosine clupeids native to the east coast of North America. Mature fish spawn in freshwater habitats from Florida to Quebec, beginning in the winter at low latitudes and progressing through the summer at high latitudes (Limburg et al. 2003). Juveniles develop in fresh water and migrate to the ocean, where they spend 3-7 years before returning to fresh water to spawn (Maki et al. 2001). Marine movements of American shad are known from extensive tagging efforts that described complex, long-distance migrations along the North American coast (Dadswell et al. 1987). Despite the potential for substantial stock mixture at sea, most American shad appear to spawn in their natal river (Waters et al. 2000; Walther et al. 2008). There is a pressing need to understand the migratory dynamics of American shad because many populations are under moratorium and stock abundances throughout their range are at historic lows (Olney and Hoenig 2001; Limburg et al. 2003).

Otolith geochemistry has proven a useful natural tag for American shad. Thorrold et al. (1998) demonstrated significant variability of elemental signatures in juvenile otoliths from three major rivers in the northeast United States. Based on a suite of elemental and isotope ratios, Walther et al. (2008) found distinct otolith signatures from 12 natal rivers along the Atlantic coast of the USA. Our present goal was to determine whether distinct signatures could be detected on a continental scale covering the entire native range of the species. We expanded upon the work of Walther et al. (2008) to include all major spawning populations of American shad (ASMFC 2007) across approximately $2700 \mathrm{~km}$ of coastline and 19 degrees of latitude. These collections span the entire extant native range of the species. Our second aim was to examine correlations between water composition and otolith elemental and isotope ratios for a subset of these rivers. Where significant, these correlations allowed otolith chemistry to be predicted for rivers where otoliths were not avail- able. Through these analyses, we aimed to create a comprehensive database of signatures for this widely distributed anadromous species, thereby laying the groundwork for future studies to identify natal origins of migrating American shad.

\section{Materials and methods}

\section{Otolith analyses}

Juvenile American shad were sampled in 2004 from 13 rivers throughout their native range between Florida and Maine (Fig. 1, Table 1). Fish were collected using push nets, seines, and trawls in freshwater and upper-estuarine regions of each river prior to their downstream migration to the oceanic environment. All fish were frozen upon collection. Collections were timed to coincide with highest abundance of juveniles in each river, beginning in January at low latitudes and proceeding through October at higher latitudes. An average of 50 fish (range 18-59) from each river was included in the analyses. Fish were unavailable from the Susquehanna and Chowan rivers, where juvenile abundance was severely reduced in 2004.

Frozen fish were thawed, measured (fork length or total length), and dissected to remove pairs of sagittal otoliths. Otoliths were rinsed in distilled water, air-dried, and mounted on glass slides with cyanoacrylic glue. Mounted otoliths were ground to the midplane using fine-grained lapping film. Ground otoliths were examined for oxytetracycline marks indicating hatchery origin under an ultraviolet (UV) light source. Hatchery-marked juveniles from the Roanoake River were not present in our collections, since they were identified and removed by the North Carolina Wildlife Resources Commission prior to analyses at our laboratory. Hatchery marks were detected in juveniles from the Kennebec $(14 \%, n=8)$, Exeter $(30 \%, n=14)$, and Rappahannock $(39 \%, n=7)$ rivers. Identifying hatchery-marked juveniles for these rivers allowed us to determine whether hatchery fish contained significantly different otolith signatures than wild individuals. After screening for hatchery marks, one otolith from each pair was randomly chosen for laser ablation analysis. This otolith was scrubbed, sonicated in ultrapure water for $2 \mathrm{~min}$, and triple-rinsed in a class-100 clean room.

Cleaned otoliths were analyzed for $\mathrm{Mg}: \mathrm{Ca}, \mathrm{Mn}: \mathrm{Ca}, \mathrm{Sr}: \mathrm{Ca}$, and $\mathrm{Ba}: \mathrm{Ca}$ ratios on a Thermo Finnigan Element2 single collector inductively coupled plasma mass spectrometer (ICP-MS) coupled to a $213 \mathrm{~nm}$ laser ablation system. A $200 \mu \mathrm{m} \times 200 \mu \mathrm{m}$ raster was ablated adjacent to the nucleus and extending to the posterior lobe. This raster covered a substantial portion of the juvenile otolith and represented approximately 1 to 3 months of early life. Elemental ratios were quantified by monitoring ${ }^{25} \mathrm{Mg},{ }^{48} \mathrm{Ca},{ }^{55} \mathrm{Mn},{ }^{86} \mathrm{Sr}$, and ${ }^{138} \mathrm{Ba}$. Analytical methods followed those of Rosenthal et al. (1999) as modified by Walther et al. (2008). A He gas stream carried ablated material to the ICP-MS, where it was mixed with an $\mathrm{Ar}$ sample gas and a wet aerosol $\left(2 \% \mathrm{HNO}_{3}\right)$ supplied by a self-aspirating $\left(20 \mu \mathrm{m} \cdot \mathrm{min}^{-1}\right)$ PFA nebulizer in the concentric region of the quartz dual inlet spray chamber. Instrument blanks of $2 \% \mathrm{HNO}_{3}$ were run at the beginning, middle, and end of a block of 10 otoliths. A dissolved otolith certified reference material (CRM, Sturgeon et al. 2005) was used to correct for instrument mass bias (Rosenthal et 
Fig. 1. Map of rivers where otoliths and water samples were collected along the North American Atlantic coast.

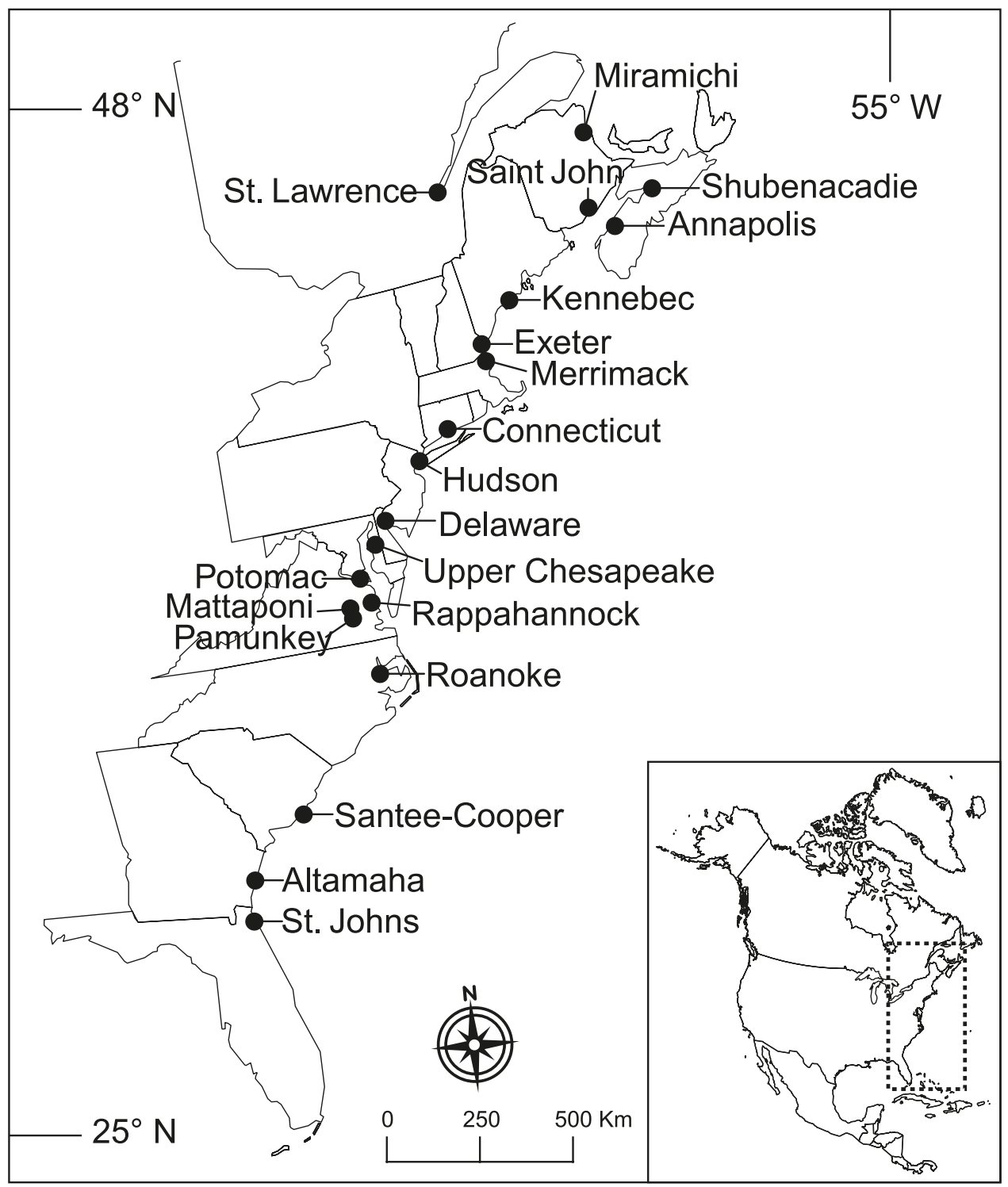

al. 1999), and instrument precision was assessed using a second otolith CRM (Yoshinaga et al. 2000). External precisions (relative standard deviations) for the second CRM ( $n=134)$ were $36 \%$ for $\mathrm{Mg}: \mathrm{Ca}, 26 \%$ for $\mathrm{Mn}: \mathrm{Ca}, 0.3 \%$ for $\mathrm{Sr}: \mathrm{Ca}$, and $1 \%$ for $\mathrm{Ba}: \mathrm{Ca}$.

After elemental analysis, the same otolith was used for ${ }^{87} \mathrm{Sr}:{ }^{86} \mathrm{Sr}$ ratio analysis using a Thermo Finnigan Neptune multiple collector ICP-MS coupled to a $213 \mathrm{~nm}$ laser ablation system. The laser software was used to trace out a $250 \mu \mathrm{m} \times 200 \mu \mathrm{m}$ raster adjacent to the nucleus, extending toward the posterior lobe of each otolith and adjacent to the raster ablated for elemental ratio measurements. Ablated material was carried by a He gas stream from the laser cell to the ICP-MS, where it was mixed with an Ar sample gas and a wet aerosol in a spray chamber as described above for the elemental analyses. In addition to ${ }^{84} \mathrm{Sr},{ }^{86} \mathrm{Sr},{ }^{87} \mathrm{Sr}$, and ${ }^{88} \mathrm{Sr}$, we monitored ${ }^{83} \mathrm{Kr}$ and ${ }^{85} \mathrm{Rb}$ to account for potential interferences on $\mathrm{Sr}$ isotopes (Barnett-Johnson et al. 2005; Jackson and Hart 2006). Following Walther et al.
(2008), the contribution of ${ }^{87} \mathrm{Rb}$ to ${ }^{87} \mathrm{Sr}$ intensities was removed by applying a mass bias correction to ${ }^{85} \mathrm{Rb}$ counts derived from measured ${ }^{88} \mathrm{Sr}:{ }^{86} \mathrm{Sr}$ ratios. $\mathrm{Kr}$ intensities were subtracted from ${ }^{84} \mathrm{Sr}$ intensities until the ${ }^{84} \mathrm{Sr}:{ }^{88} \mathrm{Sr}$ value equaled natural abundance ratios (0.006755), and that $\mathrm{Kr}$ value was used to remove ${ }^{86} \mathrm{Kr}$ contributions to ${ }^{86} \mathrm{Sr}$ intensities following Jackson and Hart (2006). All data were normalized to the National Institute of Standards and Technology (NIST) Standard Reference Materials (SRM) 987 ${ }^{87} \mathrm{Sr}:{ }^{86} \mathrm{Sr}$ value of 0.71024 based on mean ${ }^{87} \mathrm{Sr}:{ }^{86} \mathrm{Sr}$ values measured in SRM 987 for a given analysis day. Mean $\left( \pm 1\right.$ standard deviation, SD) values of ${ }^{87} \mathrm{Sr}:{ }^{86} \mathrm{Sr}$ values in the SRM $987(n=41)$ and an otolith CRM $(n=74)$ run throughout the analyses were $0.71025 \pm 0.00002$ and $0.70916 \pm 0.00002$, respectively. True values of ${ }^{87} \mathrm{Sr}:{ }^{86} \mathrm{Sr}$ are 0.71024 for SRM 987 and 0.70918 for the otolith CRM, both of which are within $1 \mathrm{SD}$ of mean measured ratios.

The second ground otolith from each juvenile was ana- 
Table 1. Juvenile American shad (Alosa sapidissima) and water samples collected to groundtruth signatures in each spawning location.

\begin{tabular}{llll}
\hline River & $\begin{array}{l}\text { Juveniles } \\
(n)\end{array}$ & $\begin{array}{l}\text { Length } \\
(\mathrm{mm})\end{array}$ & $\begin{array}{l}\text { Water samples } \\
(n)\end{array}$ \\
\hline Miramichi & - & - & 5 \\
St. Lawrence & - & - & 4 \\
Shubenacadie & - & - & 4 \\
Saint John & - & - & 4 \\
Annapolis & - & - & 3 \\
Kennebec & 58 & $52 \pm 7$ & 4 \\
Exeter & 41 & $61 \pm 8$ & - \\
Merrimack & - & - & 5 \\
Connecticut & 51 & $58 \pm 9$ & 5 \\
Hudson & 54 & $71 \pm 9$ & 5 \\
Delaware & 57 & $75 \pm 9$ & - \\
Upper Chesapeake & 58 & $72 \pm 7$ & - \\
Potomac & 57 & $52 \pm 5$ & - \\
Rappahannock & 18 & $60 \pm 8$ & - \\
Mattaponi & 59 & $58 \pm 7$ & 5 \\
Pamunkey & - & - & 5 \\
Roanoke & 57 & $81 \pm 10$ & - \\
Santee-Cooper & 57 & $52 \pm 4$ & - \\
Altamaha & 26 & $84 \pm 6$ & - \\
St. Johns & 59 & $78 \pm 7$ & 5 \\
\hline
\end{tabular}

Note: Fish lengths (mean \pm standard deviation) are total lengths for the Exeter and Roanoke rivers and fork lengths for all remaining rivers.

lyzed for $\delta^{18} \mathrm{O}$ values using isotope ratio mass spectrometry (IR-MS). A computer-controlled micromill removed a $400 \mu \mathrm{m} \times 400 \mu \mathrm{m}$ raster with a $75 \mu \mathrm{m}$ drilling depth. This larger raster incorporated more juvenile material and represented approximately 3 to 4 months of life. However, since all juveniles were captured prior to emigration from fresh water, there was no possibility of incorporating material that represented non-natal habitats. Each milled raster was adjacent to the nucleus and extended toward the posterior lobe. The resulting powder was weighed and transferred to individual glass sample vials. Mean mass $(n=653)$ of the sampled powder was $46 \pm 15 \mu \mathrm{g}$ ( $1 \mathrm{SD})$. Samples were analyzed on a Thermo Finnigan MAT252 equipped with a Kiel III carbonate device following methods outlined by Ostermann and Curry (2000). Isotopic values were reported relative to Vienna Pee Dee Belemnite (VPDB) and expressed in standard $\delta$ notation. The long-term precision estimate of the mass spectrometer based on analyses of NBS19 (NIST SRM 8544 ) is \pm 0.07 for $\delta^{18} \mathrm{O}$ (Ostermann and Curry 2000).

\section{Water sample analyses}

Water samples were collected from 12 rivers along the Atlantic Coast (Fig. 1, Table 1). Samples were taken from three to five locations along the main stem of each river, ranging from just above the salt wedge to the highest region currently accessible by spawning shad, usually determined by a major dam. Collections were made between late August and early October 2004. At each location, $50 \mathrm{~mL}$ of river water was collected for $\mathrm{Mg}: \mathrm{Ca}, \mathrm{Mn}: \mathrm{Ca}, \mathrm{Sr}: \mathrm{Ca}, \mathrm{Ba}: \mathrm{Ca}$, and ${ }^{87} \mathrm{Sr}:{ }^{86} \mathrm{Sr}$ ratio analysis. Water was filtered through $0.2 \mu \mathrm{m}$
Nalgene PTFE (polytetrafluoroethylene) filters with syringes into acid-washed LDPE (low-density polyethylene) bottles and acidified $(2 \%)$ using concentrated, ultrapure $\mathrm{HNO}_{3}$. All plastic materials used for sample collection were acidwashed prior to use. An additional $60 \mathrm{~mL}$ of river water for $\delta^{18} \mathrm{O}$ ratios was filtered into glass vials and sealed with airtight screw caps. These samples were not acidified. Samples were kept on ice in the field and refrigerated upon return to the laboratory.

Water samples were diluted 10-fold with $2 \% \mathrm{HNO}_{3}$ and analyzed using solution-based ICP-MS to measure ${ }^{24} \mathrm{Mg}$, ${ }^{43} \mathrm{Ca},{ }^{55} \mathrm{Mn},{ }^{88} \mathrm{Sr}$, and ${ }^{138} \mathrm{Ba}$ on a Thermo Finnigan Element2 single collector as described above. Liquid standards and instrument blanks of $2 \% \mathrm{HNO}_{3}$ were run every six samples. Instrument mass bias was corrected for using certified values of a river water standard (SLRS-4, National Research Council (NRC)), and an internal laboratory river water standard was used to assess measurement precision. External precisions (relative standard deviations) for the laboratory standard $(n=20)$ were $0.6 \%$ for $\mathrm{Mg}: \mathrm{Ca}, 0.5 \%$ for $\mathrm{Mn}: \mathrm{Ca}$, $0.5 \%$ for $\mathrm{Sr}: \mathrm{Ca}$, and $0.9 \%$ for $\mathrm{Ba}: \mathrm{Ca}$.

Prior to analysis of ${ }^{87} \mathrm{Sr}:{ }^{86} \mathrm{Sr}$ ratios in river water, a $20 \mathrm{~mL}$ aliquot of each sample was evaporated to dryness, redissolved in $50 \% \mathrm{HNO}_{3}$, and passed through columns containing Sr Resin (Eichrom Technologies). This Sr-specific ion exchange resin $\left(4,4^{\prime},\left(5^{\prime}\right)\right.$-di-t-butylcyclohexano-18-crown-6) separates $\mathrm{Sr}$ from other constituents in the water samples via sequential elutions with ultrapure water and $50 \%$ ultrapure $\mathrm{HNO}_{3}$. After $\mathrm{Sr}$ separation, the sample was again evaporated to dryness and then redissolved in $1 \mathrm{~mL}$ of $5 \%$ $\mathrm{HNO}_{3}$ for $\mathrm{Sr}$ isotope analysis using a Thermo Finnigan Neptune multiple collector ICP-MS. Data were corrected for isotopic interferences as described above for otolith analyses. The mean $( \pm 1 \mathrm{SD})$ value of ${ }^{87} \mathrm{Sr}:{ }^{86} \mathrm{Sr}$ values in SRM $987(n=6)$ run throughout the analyses was $0.71026 \pm$ 0.00002 , which compares favorably with the accepted value of 0.71024 for SRM 987.

The $\delta^{18} \mathrm{O}$ ratios of water samples were quantified by equilibrating $0.5 \mathrm{~cm}^{3}$ of sample with $\mathrm{CO}_{2}$ at atmospheric pressure following methods described by Epstein and Mayeda (1953). The resulting gas was transferred from the water equilibration system to a Europa GEO 20-20 dual-inlet mass spectrometer. Method precision based on measurements of an internal standard was $\pm 0.08 \%$ for $\delta^{18} \mathrm{O}$ (Swart and Price 2002). Data are reported relative to Vienna Standard Mean Ocean Water (VSMOW) using the standard $\delta$ notation.

\section{Statistical analyses}

Correlations between water and otolith chemistry were examined using juvenile otoliths and river water samples from the Kennebec, Connecticut, Hudson, Mattaponi, and St. Johns rivers. Linear regressions were fitted to scatterplots of mean ratios of juvenile otoliths against mean river water ratios for all chemical signatures. Mean ratios were used because individual otoliths and water samples were not paired.

Linear regression was used to predict mean otolith values based on mean water sample ratios for those rivers where no juveniles were collected. An estimate of the error about pre- 
Fig. 2. Regressions of mean \pm 1 standard deviation (SD) otolith elemental and isotope ratios against mean water \pm 1 SD ratios. Values are for the five rivers where both otoliths and water samples were collected. Regression equations are calculated using mean values. Slopes of $\delta^{18} \mathrm{O},{ }^{87} \mathrm{Sr}:{ }^{86} \mathrm{Sr}$, Sr:Ca, and Ba:Ca ratios are statistically significant. (a) $\delta^{18} \mathrm{O}$ ratios (VPDB, Vienna Pee Dee Belemnite; VSMOW, Vienna Standard Mean Ocean Water), (b) ${ }^{87} \mathrm{Sr}:{ }^{86} \mathrm{Sr}$ ratios (1:1 relationship is shown as a broken line), (c) Sr:Ca ratios, (d) Ba:Ca ratios, (e) Mg:Ca ratios, $(f) \mathrm{Mn}$ :Ca ratios.
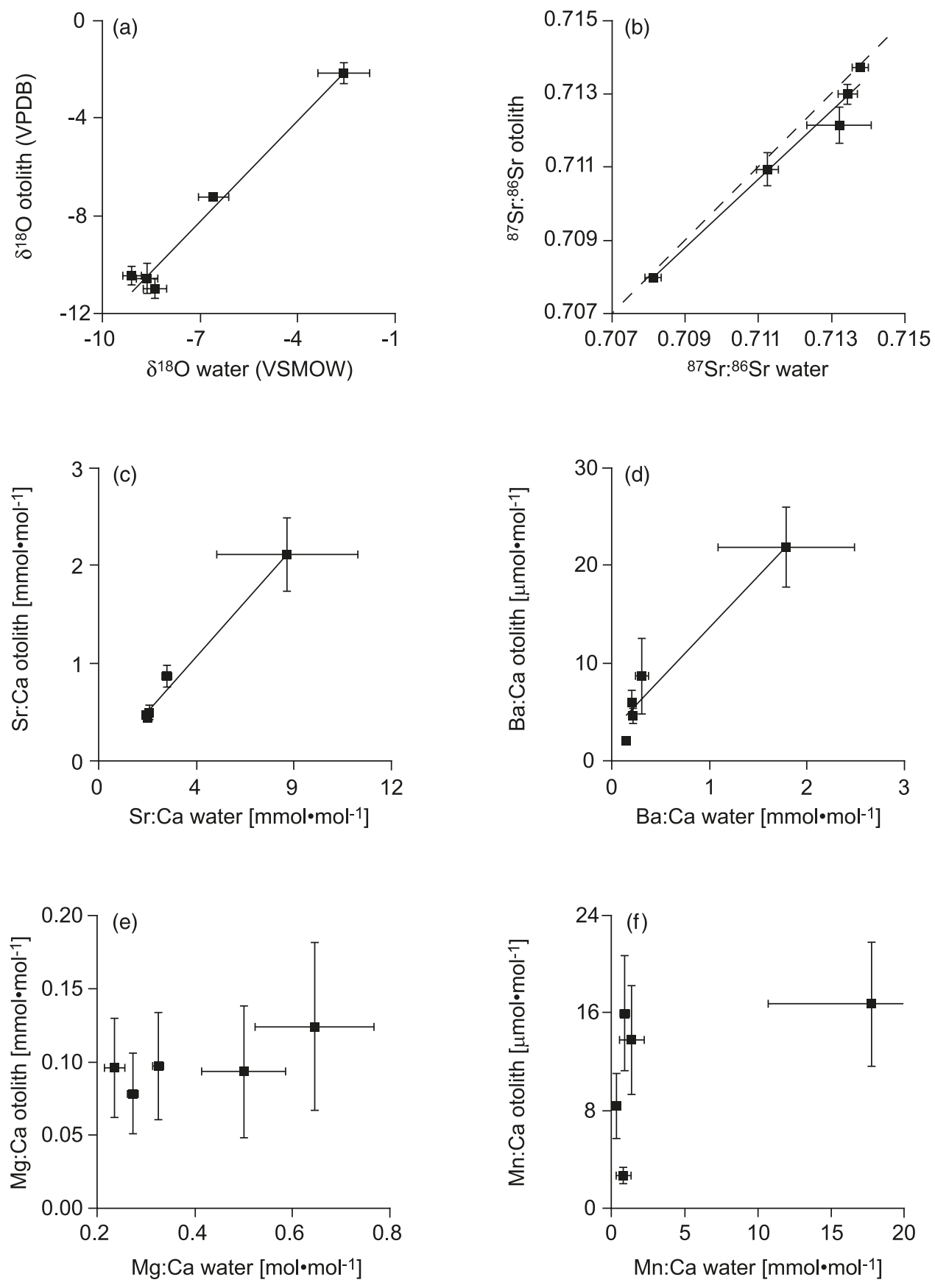

dicted otolith means was calculated using the equation for the standard error of the prediction error:

(1) $\quad \mathrm{SE}_{\text {oto }}=\sqrt{s^{2}+s_{\widehat{Y}}^{2}}$

where $s^{2}$ is the estimated variance of the regression, and $s_{\widehat{Y}}^{2}$ is the variance of the predicted mean otolith ratio for a given mean river ratio (Devore 2004). The standard error of the prediction error was chosen because it accounted for the greater uncertainty inherent in predicting one random variable (an otolith ratio) from another (a water ratio). The exception was ${ }^{87} \mathrm{Sr}:{ }^{86} \mathrm{Sr}$ ratios, where water values were used as direct predictors of the means 
Fig. 3. (a) $\delta^{18} \mathrm{O}$ values (VPDB, Vienna Pee Dee Belemnite), (b) Sr:Ca ratios, and (c) Ba:Ca ratios of predicted (open symbols) and actual (solid symbols) otolith signatures for the five rivers where water and otoliths were collected. Rivers were sequentially excluded, and predictions of otolith signatures were based on regressions calculated using the remaining four rivers. (d) Comparison of river water (open symbols) and otolith signatures (solid signatures) of ${ }^{87} \mathrm{Sr}:{ }^{86} \mathrm{Sr}$ ratios. River water ${ }^{87} \mathrm{Sr}:{ }^{86} \mathrm{Sr}$ ratios and errors were used to directly estimate otolith signatures, so a regression prediction test was not performed as for the other three signatures. For all graphs, means and \pm 1 standard deviations (SD) are shown; SDs smaller than the symbols are not shown.
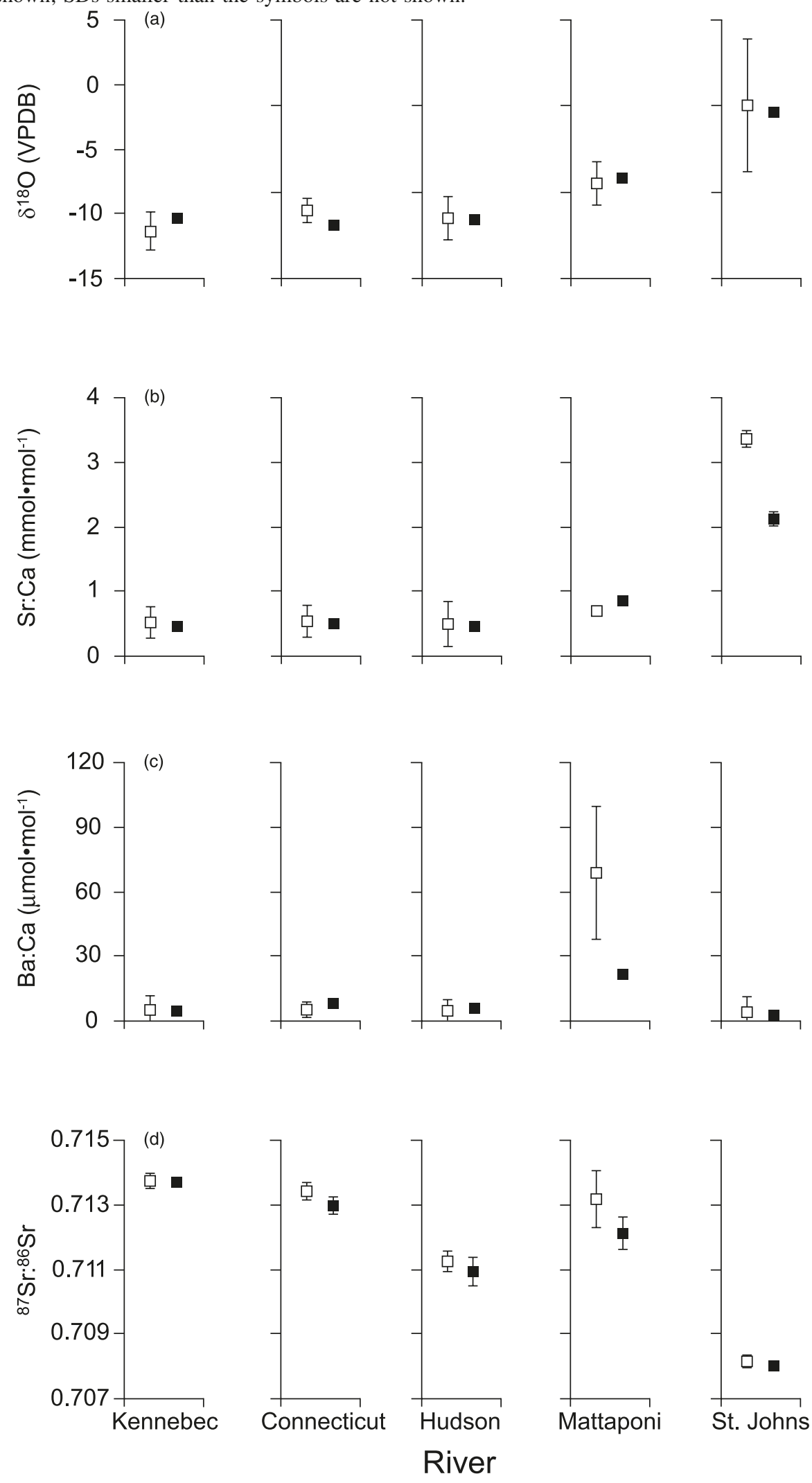
Fig. 4. Elemental and isotope ratios of juvenile otoliths (solid symbols) and water samples (open symbols). Values are means \pm 1 standard deviation (SD); SDs smaller than the symbols are not shown. Water samples are displayed for rivers where no juveniles were collected. Rivers are arranged in latitudinal order from north to south along the $x$ axis. (a) $\delta^{18} \mathrm{O}$ values; units are Vienna Pee Dee Belemnite (VPDB) for otoliths, Vienna Standard Mean Ocean Water (VSMOW) for water. (b) ${ }^{87} \mathrm{Sr}:{ }^{86} \mathrm{Sr}$ ratios. (c) $\mathrm{Sr}$ :Ca ratios; units are $\mathrm{mmol} \cdot \mathrm{mol}^{-1}$ for water, $\mathrm{mmol} \cdot \mathrm{mol}^{-1} \times 10$ for otoliths. $(d) \mathrm{Ba}$ :Ca ratios; units are $\mathrm{mmol} \cdot \mathrm{mol}^{-1} \times 10$ for water, $\mu \mathrm{mol} \cdot \mathrm{mol}^{-1}$ for otoliths.
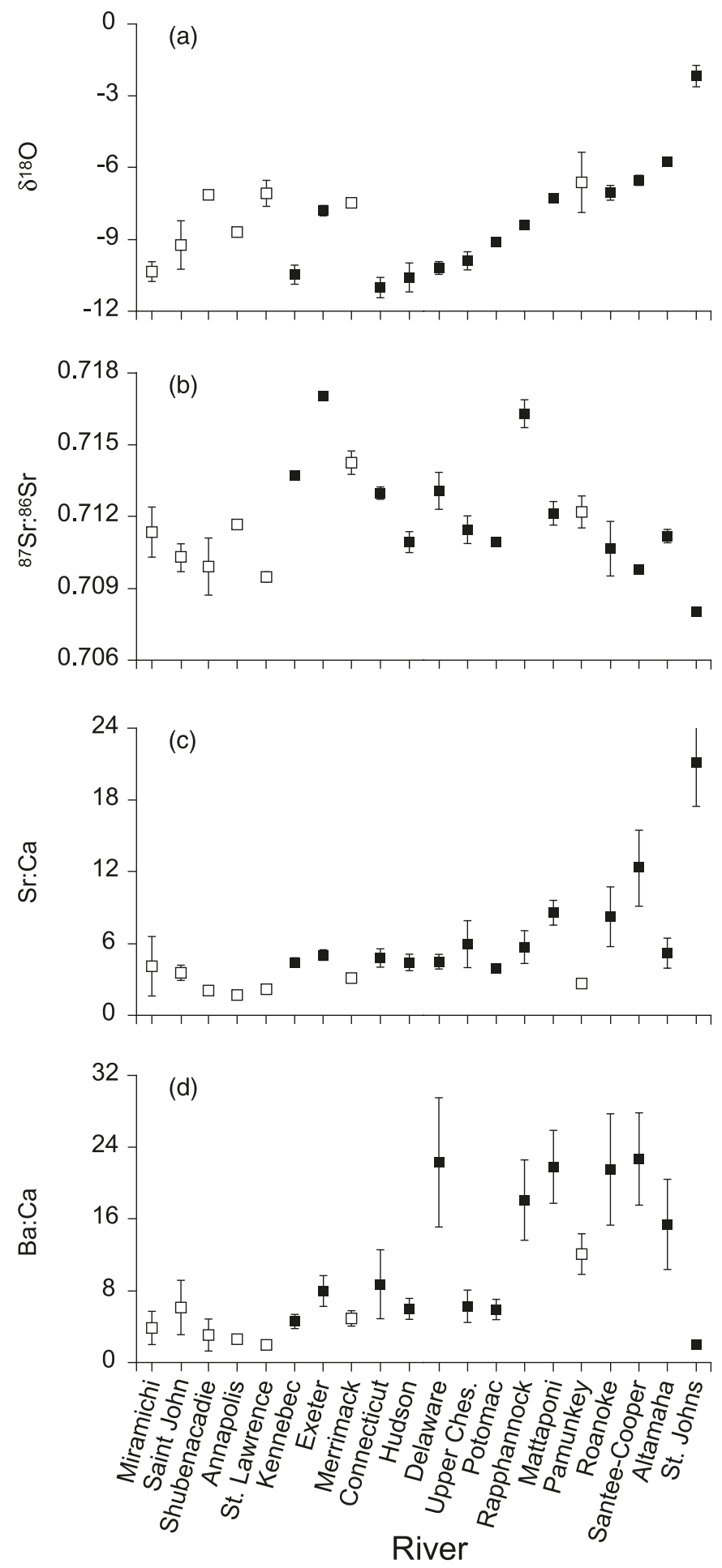

and standard errors of otolith ${ }^{87} \mathrm{Sr}:{ }^{86} \mathrm{Sr}$ ratios. We assumed that any deviation from a $1: 1$ line between ${ }^{87} \mathrm{Sr}:{ }^{86} \mathrm{Sr}$ values in otoliths and water was due to random errors, because there is no empirical or theoretical support for nonequilibrium deposition of $\mathrm{Sr}$ isotopes in fish otoliths (Kennedy et al. 1997, 2000).

We tested the ability of our regression technique to accurately estimate otolith $\delta^{18} \mathrm{O}, \mathrm{Sr}: \mathrm{Ca}$, and $\mathrm{Ba}: \mathrm{Ca}$ signatures based on water composition using the five rivers where both otolith and water samples were collected. To assess the accuracy of our regression technique for $\delta^{18} \mathrm{O}, \mathrm{Sr}: \mathrm{Ca}$, and $\mathrm{Ba}: \mathrm{Ca}$ signatures, we sequentially excluded each of the five rivers and recalculated the regression between water and otolith chemistry using the four remaining rivers. We then estimated the mean and standard error of each variable for the excluded river based on the recalculated regressions. We compared the estimated otolith means and standard errors with the observed means and standard errors for each variable in each excluded river. This simultaneously allowed us to assess the influence of individual rivers on the regression equations and determine whether the regression technique adequately constrained predicted otolith ratios.

For each of the seven rivers where no juveniles were collected, 50 fish were simulated with a normal distribution random number algorithm based on predicted otolith ratios and standard errors. A quadratic discriminant function analysis (DFA) was performed on the entire database of simulated and actual otolith signatures from 20 rivers. The DFA used a jackknife cross-validation procedure to determine classification accuracy and distinctness of signatures among rivers. The inclusion of hatchery-marked juveniles did not affect the results of the DFA, and they were therefore pooled with nonhatchery juveniles.

To further confirm that our regression procedure did not bias our predictions of otolith signatures, we compared classification accuracies for simulated and real otoliths for those five rivers used in the regression relationship. First, we restricted our quadratic DFA to only those rivers where juvenile otoliths were present. Classification accuracies for these rivers were close or identical to those obtained with the full database of simulated and actual otolith signatures. Next, we sequentially removed each of the five rivers involved in the regression from the relationship, recalculated the regressions for each chemical signature, and predicted means and errors of otolith compositions for the removed river, as described above. Using those means and errors, we simulated 50 otolith signatures for each of the removed rivers. We then calculated five separate quadratic DFAs, replacing the actual otoliths with simulated otoliths for the excluded river.

\section{Results}

Development of a comprehensive, groundtruthed atlas of geochemical signatures in the otoliths of juvenile American shad depended on our ability to reconstruct otolith compositions for rivers where we only collected water samples. We therefore compared water and otolith chemistry from those rivers (Kennebec, Connecticut, Hudson, Mattaponi, and St. Johns) where both juvenile American shad otoliths and water samples were collected. It was possible to predict oto- 
Table 2. Cross-validation summary from the quadratic discriminant function analysis run on signatures from actual and simulated

\begin{tabular}{|c|c|c|c|c|c|c|c|c|}
\hline River & Mira & StLw & Shub & StJn & Anna & Kenne & Exet & Merri \\
\hline Mira & 98 (49) & - & - & $2(1)$ & - & - & - & - \\
\hline StLw & - & $94(47)$ & $6(3)$ & - & - & - & - & - \\
\hline Shub & - & $14(7)$ & $80(40)$ & - & - & - & - & - \\
\hline StJn & $2(1)$ & - & - & 98 (49) & - & - & - & - \\
\hline Anna & - & - & - & - & $94(47)$ & - & - & - \\
\hline Kenne & - & - & - & - & - & $100(58)$ & - & - \\
\hline Exet & - & - & - & - & - & - & $100(41)$ & - \\
\hline Merri & - & - & - & - & - & - & - & $100(50)$ \\
\hline Conn & - & - & - & - & - & - & - & $2(1)$ \\
\hline Huds & - & $2(1)$ & - & - & 7 (4) & - & - & - \\
\hline Dela & - & - & - & - & - & - & - & - \\
\hline UpCh & $2(1)$ & - & - & - & $2(1)$ & - & - & - \\
\hline Poto & - & - & $9(5)$ & - & - & - & - & - \\
\hline Rapp & - & - & - & - & - & - & - & - \\
\hline Matt & - & - & - & - & - & - & - & - \\
\hline Pamu & - & - & - & - & - & - & - & - \\
\hline Roan & - & - & $2(1)$ & - & - & - & - & - \\
\hline $\mathrm{SaCo}$ & - & - & - & - & - & - & - & - \\
\hline Alta & - & - & - & - & - & - & - & - \\
\hline StJs & - & - & - & - & - & - & - & - \\
\hline
\end{tabular}

Note: Reported values are percent classification and numbers of individuals (in parentheses) assigned to each location (indicated by columns). Accurate no classifications. River codes are as follows: Mira, Miramichi River, New Brunswick; StLw, St. Lawrence River, Quebec; Shub, Shubenacadie River, Nova Hampshire; Merri, Merrimack River, Massachusetts; Conn, Connecticut River, Connecticut; Huds, Hudson River, New York; Dela, Delaware River, New Virginia; Pamu, Pamunkey River, Virginia; Roan, Roanoke River, North Carolina; SaCo, Santee-Cooper River, South Carolina; Alta, Altmaha River, Geor-

lith values based on water chemistry data from some, but not all, of the variables that we examined. Four of the six variables showed significant positive linear regressions $(p<$ 0.01 ) between water and otolith chemistry (Fig. 2). The relation between $\mathrm{Sr}: \mathrm{Ca}$ ratios $\left(\mathrm{mmol} \cdot \mathrm{mol}^{-1}\right)$ in river water $\left(\mathrm{Sr}: \mathrm{Ca}_{\mathrm{water}}\right)$ and otoliths $\left(\mathrm{Sr}: \mathrm{Ca}_{\mathrm{oto}}\right)$ was given by

$$
\begin{aligned}
\mathrm{Sr}: \mathrm{Ca}_{\mathrm{oto}}=0.29 & ( \pm 0.02 \mathrm{SE}) \cdot \mathrm{SR}: \mathrm{Ca}_{\text {water }} \\
& -0.08( \pm 0.07 \mathrm{SE}) \quad\left(r^{2}=0.99\right)
\end{aligned}
$$

The relation between $\mathrm{Ba}: \mathrm{Ca}\left(\mu \mathrm{mol} \cdot \mathrm{mol}^{-1}\right)$ in water $\left(\mathrm{Ba}: \mathrm{Ca}_{\text {water }}\right)$ and in otoliths $\left(\mathrm{Ba}: \mathrm{Ca}_{\text {oto }}\right)$ was given by

$$
\begin{aligned}
\mathrm{Ba}: \mathrm{Ca}_{\text {oto }}=0.01( & \pm 0.001 \mathrm{SE}) \cdot \mathrm{Ba}: \mathrm{Ca}_{\mathrm{water}} \\
+ & 2.80( \pm 1.2 \mathrm{SE}) \quad\left(r^{2}=0.94\right)
\end{aligned}
$$

Otolith $\delta^{18} \mathrm{O}$ values $\left(\delta^{18} \mathrm{O}_{\text {oto }}, \mathrm{VPDB}\right)$ accurately reflected those of the ambient water $\left(\delta^{18} \mathrm{O}_{\text {water }}, \mathrm{VSMOW}\right)$ according to the following regression:

$$
\begin{aligned}
\delta^{18} \mathrm{O}_{\text {oto }}=1.4( \pm 0.1 \mathrm{SE}) \cdot \delta^{18} \mathrm{O}_{\text {water }} & \\
& +1.5( \pm 0.9 \mathrm{SE}) \quad\left(r^{2}=0.98\right)
\end{aligned}
$$

The regression between water and otolith ${ }^{87} \mathrm{Sr}:{ }^{86} \mathrm{Sr}$ ratios deviated only slightly from the 1:1 line:

$$
\begin{aligned}
{ }^{87} \mathrm{Sr}:{ }^{86} \mathrm{Sr}_{\text {oto }}= & 0.94( \pm 0.09 \mathrm{SE}) \cdot{ }^{87} \mathrm{Sr}:{ }^{86} \mathrm{Sr}_{\text {water }} \\
& +0.04( \pm 0.06 \mathrm{SE}) \quad\left(r^{2}=0.97\right)
\end{aligned}
$$

These data confirmed that otolith ${ }^{87} \mathrm{Sr}:{ }^{86} \mathrm{Sr}$ ratios directly reflect those of the ambient water. However, variations in otolith $\mathrm{Mg}: \mathrm{Ca}$ and $\mathrm{Mn}: \mathrm{Ca}(p>0.05)$ showed no detectable dependence on dissolved ratios measured in river water sam- ples (Fig. 2). We therefore excluded $\mathrm{Mg}: \mathrm{Ca}$ and $\mathrm{Mn}: \mathrm{Ca}$ from all subsequent analyses.

Our regression technique was generally accurate at estimating mean otolith signatures and conservative in predicting standard errors (Fig. 3). Most predicted mean signatures were within $1 \mathrm{SD}$ of the actual mean. Importantly, predicted otolith SDs were generally at least an order of magnitude larger than the observed SDs. There was, therefore, considerably more variation in water chemistry along a river than was recorded in the juvenile shad otoliths. Presumably this observation was due to the fact that individual juvenile shad were integrating these differences in water chemistry in a similar manner. In any case, our prediction procedure was conservative and provided a much wider range of possible values within a river when compared with observed data in actual otoliths from a given river. This procedure also allowed for expected variability in ambient water chemistry during the juvenile residency period in each river. Predicted and observed Sr:Ca ratios for the St. Johns river were substantially displaced from one another, indicating this river was a high leverage point in the combined regression for this elemental ratio. However, this leverage reflects the true range of ambient Sr:Ca ratios; the St. Johns River is significantly more elevated in $\mathrm{Sr}: \mathrm{Ca}$ than the remaining four rivers. Similarly, predicted and observed $\mathrm{Ba}: \mathrm{Ca}$ ratios from the Mattaponi River differed significantly, suggesting that this river also represented a high leverage point for the regression analysis. Again, however, Ba:Ca ratios in the Mattaponi River were higher than those in the other four rivers. When these rivers were removed from the regression calculations for both $\mathrm{Sr}: \mathrm{Ca}$ and $\mathrm{Ba}: \mathrm{Ca}$ ratios, the regressions calculated based on the remaining rivers resulted in inaccurate predictions of otolith composition for the Mattaponi and St. Johns 
otoliths ( $n=1003$, hatchery fish included).

\begin{tabular}{|c|c|c|c|c|c|c|c|c|c|c|c|}
\hline Conn & Huds & Dela & $\mathrm{UpCh}$ & Poto & Rapp & Matt & Pamu & Roan & $\mathrm{SaCo}$ & Alta & StJs \\
\hline - & - & - & - & - & - & - & - & - & - & - & - \\
\hline - & - & - & - & - & - & - & - & - & - & - & - \\
\hline - & - & - & - & $6(3)$ & - & - & - & - & - & - & - \\
\hline - & - & - & - & - & - & - & - & - & - & - & - \\
\hline- & $4(2)$ & - & $2(1)$ & - & - & - & - & - & - & - & - \\
\hline- & - & - & - & - & - & - & - & - & - & - & - \\
\hline- & - & - & - & - & - & - & - & - & - & - & - \\
\hline- & - & - & - & - & - & - & - & - & - & - & - \\
\hline $90(46)$ & - & $6(3)$ & - & - & - & - & $2(1)$ & - & - & - & - \\
\hline- & $83(45)$ & - & $2(1)$ & $6(3)$ & - & - & - & - & - & - & - \\
\hline - & - & $93(53)$ & 7 (4) & - & - & - & - & - & - & - & - \\
\hline- & $5(3)$ & $2(1)$ & $89(52)$ & - & - & - & - & - & - & - & - \\
\hline- & - & - & - & $91(52)$ & - & - & - & - & - & - & - \\
\hline- & - & - & - & - & $100(18)$ & - & - & - & - & - & - \\
\hline- & - & - & - & - & - & $88(52)$ & $5(3)$ & $7(4)$ & - & - & - \\
\hline- & - & $2(1)$ & $2(1)$ & - & - & $6(3)$ & $86(43)$ & $4(2)$ & - & - & - \\
\hline- & - & - & - & - & - & $2(1)$ & - & $96(55)$ & - & - & - \\
\hline- & - & - & - & - & - & - & - & $2(1)$ & $98(56)$ & - & - \\
\hline- & - & - & - & - & - & - & $4(1)$ & $8(2)$ & - & 88 (23) & - \\
\hline- & - & - & - & - & - & - & - & - & - & - & $100(59)$ \\
\hline
\end{tabular}

classifications to group of origin are shown on the diagonal; accuracies sum to $100 \%$ across a row for a given source group. Long dashes indicate Scotia; StJn, Saint John River, New Brunswick; Anna, Annapolis River, Nova Scotia; Kenne, Kennebec River, Maine; Exe, Exeter River, New Jersey; UpCh, Upper Chesapeake Bay, Maryland; Poto, Potomac River, Maryland; Rapp, Rappahannock River, Virginia; Matt, Mattaponi River, gia; StJs, St. Johns River, Florida.

rivers. It was therefore important that all five rivers be included in the combined regression for $\mathrm{Sr}: \mathrm{Ca}$ and $\mathrm{Ba}: \mathrm{Ca}$ to fully account for the range of possible values across the sampled geographic region.

Elemental and isotope ratios measured in otoliths and water samples varied substantially among rivers (Fig. 4). We found systematic variations in $\delta^{18} \mathrm{O}$ values along the latitudinal gradient of individual watersheds, although the pattern was less clear with the inclusion of coastal Canadian rivers. Both $\mathrm{Sr}: \mathrm{Ca}$ and $\mathrm{Ba}: \mathrm{Ca}$ were characterized by elevated ratios in many southern rivers, although there was higher within-river variability for both ratios than we observed for $\delta^{18} \mathrm{O}$ values. Finally, ${ }^{87} \mathrm{Sr}:{ }^{86} \mathrm{Sr}$ ratios showed lower variation among samples within an individual river than the elemental ratios, and with no obvious latitudinal gradient.

We restricted analyses of geochemical signatures among rivers to the four elemental and isotope ratios $(\mathrm{Sr}: \mathrm{Ca}$, $\mathrm{Ba}: \mathrm{Ca}, \delta^{18} \mathrm{O}$, and ${ }^{87} \mathrm{Sr}:{ }^{86} \mathrm{Sr}$ ) for which otolith values could be predicted from water samples. DFA was used to analyze measured or simulated otolith signatures in juvenile American shad collected from a total 20 rivers. Cross-validated classification accuracies ranged from $80 \%$ to $100 \%$, with an average rate of $93 \%$ (Table 2). Misclassifications were generally restricted to only a few fish per river. Most misclassified juveniles were assigned to rivers in the same geographic region as their natal river. For instance, all seven misclassified juveniles from the Shubenacadie River were assigned to the St. Lawrence River. Mean classification accuracy of simulated otoliths based on water chemistry measurements from rivers where juveniles were not collected $(93 \%)$ was comparable with the mean classification rate of those rivers where only juvenile otoliths were as- sayed (96\%, Table 3). Importantly, our regression procedure did not substantially bias our estimates of classification accuracies. Classification accuracies were similar regardless of whether actual or simulated otoliths were used for the Kennebec, Connecticut, Hudson, Mattaponi, or St. Johns rivers (Table 3).

Canonical structure coefficients indicated the relative importance of the four variables to the separation in geochemical signatures among rivers (Table 4). The absolute value of the coefficient indicates the relative importance of the ratio in driving combined signature separation along that variate, while the sign describes the direction of the relationship. The first canonical variate was primarily driven by a strong latitudinal cline in $\delta^{18} \mathrm{O}$ values, with values becoming isotopically lighter with increasing latitude (Fig. 2a). Strontium isotopes and $\mathrm{Sr}: \mathrm{Ca}$ ratios also contributed to separation among rivers on the first canonical variate. Excluding the Canadian rivers, ${ }^{87} \mathrm{Sr}:{ }^{86} \mathrm{Sr}$ ratios typically increased, while $\mathrm{Sr}$ :Ca ratios decreased, from low to high latitudes. Loadings on the second canonical variate were dominated by regional variation in ${ }^{87} \mathrm{Sr}:{ }^{86} \mathrm{Sr}$ ratios (Fig. $2 b$ ), with a smaller contribution from $\delta^{18} \mathrm{O}$ ratios. Finally, $\mathrm{Ba}: \mathrm{Ca}$ ratios appeared to contribute minimally to signature separation along the first variate and moderately to separation along the second variate.

\section{Discussion}

Geochemical signatures in otoliths and water collected from 20 major spawning rivers along the Atlantic coast of the United States and Canada were excellent natural tags of natal origins in American shad. Cross-validation classification accuracies of individual fish based on these signatures 
Table 3. Cross-validated classification accuracies (\%) for quadratic discriminant function analyses (DFAs).

\begin{tabular}{|c|c|c|c|c|c|c|c|c|c|c|c|c|c|c|}
\hline DFA & Kenne & Exet & Conn & Huds & Dela & $\mathrm{UpCh}$ & Poto & Rapp & Matt & Roan & $\mathrm{SaCo}$ & Alta & StJs & Average \\
\hline (a) & 100 & 100 & 94 & 91 & 93 & 93 & 96 & 100 & 92 & 96 & 98 & 92 & 100 & 96 \\
\hline (b) & 98 & 100 & 92 & 91 & 93 & 93 & 96 & 100 & 92 & 96 & 98 & 92 & 100 & 95 \\
\hline$(c)$ & 95 & 100 & 94 & 91 & 93 & 93 & 96 & 100 & 92 & 96 & 98 & 92 & 100 & 95 \\
\hline$(d)$ & 100 & 100 & 94 & 86 & 93 & 95 & 96 & 100 & 92 & 96 & 98 & 92 & 100 & 96 \\
\hline$(e)$ & 100 & 100 & 94 & 91 & 93 & 93 & 96 & 100 & 100 & 98 & 98 & 92 & 100 & 97 \\
\hline$(f)$ & 100 & 100 & 94 & 91 & 93 & 93 & 96 & 100 & 92 & 96 & 98 & 92 & 100 & 96 \\
\hline
\end{tabular}

Note: (a) Classification accuracies for actual otoliths only. All remaining DFAs substituted simulated otoliths for actual otoliths using regressions excluding the simulated river in question: $(b)$ Kennebec River, $(c)$ Connecticut River, $(d)$ Hudson River, $(e)$ Mattaponi River, $(f)$ St. Johns River. River codes are given in Table 2; bold text indicates the substituted simulated otoliths.

Table 4. Total canonical structure coefficients from the discriminant function analysis performed on actual and simulated otoliths.

\begin{tabular}{lcl}
\hline Ratio & Variate 1 & Variate 2 \\
\hline$\delta^{18} \mathrm{O}$ & 0.887 & 0.452 \\
$\mathrm{Sr}: \mathrm{Ca}$ & 0.672 & 0.085 \\
${ }^{87} \mathrm{Sr}:{ }^{86} \mathrm{Sr}$ & -0.733 & 0.672 \\
$\mathrm{Ba}: \mathrm{Ca}$ & 0.108 & 0.182 \\
\hline
\end{tabular}

using DFA averaged $93 \%$ and were as high as $100 \%$ for five of the rivers. These results agree with previous, more limited work on American shad otolith signatures. Thorrold et al. (1998) were able to distinguish juvenile American shad from the Hudson, Connecticut, and Delaware rivers based on $\mathrm{Mg}: \mathrm{Ca}, \mathrm{Mn}: \mathrm{Ca}, \mathrm{Sr}: \mathrm{Ca}$, and $\mathrm{Ba}: \mathrm{Ca}$ in otoliths. Walther et al. (2008) added C, O, and Sr isotopes to the suite of elements assayed by Thorrold and co-workers and were able to accurately distinguish among juvenile American shad from 12 rivers. We expanded the database to include all major spawning rivers from throughout the native range of American shad, providing a comprehensive assessment of otolith signature variation for this species in 2004. Moreover, our analyses were restricted to variables for which otolith composition could be accurately predicted based on the water chemistry of ambient natal environments. This, in turn, allowed us to groundtruth geochemical signatures in rivers where it was only possible to obtain water samples.

Water chemistry can be used to predict otolith chemistry providing there is a strong correlation between the two variables in natural environments. Experimental work has demonstrated strong effects of ambient $\mathrm{Sr}$ and $\mathrm{Ba}$ concentrations on otolith composition (e.g., Bath et al. 2000; Elsdon and Gillanders 2003; Kraus and Secor 2004). We also found that $\mathrm{Sr}: \mathrm{Ca}$ and $\mathrm{Ba}: \mathrm{Ca}$ in juvenile American shad otoliths were correlated with ambient levels in river waters. In contrast, neither $\mathrm{Mg}$ : $\mathrm{Ca}$ nor $\mathrm{Mn}: \mathrm{Ca}$ ratios in otoliths were correlated with dissolved levels in the ambient water in our study. Limited experimental evidence has also suggested that variations in otolith $\mathrm{Mn}: \mathrm{Ca}$ ratios are not related to dissolved $\mathrm{Mn}: \mathrm{Ca}$ ratios (Elsdon and Gillanders 2003), while the relationship between water and otolith $\mathrm{Mg}$ has not been addressed experimentally. Both $\mathrm{Mg}$ and $\mathrm{Mn}$ play important roles in metabolic processes yet are toxic at high concentrations (Lehman and Joyce 1993; Rainbow 1997). Fish may regulate $\mathrm{Mg}$ and $\mathrm{Mn}$ concentrations to physiologically optimum levels, decoupling otolith composition from that of ambient waters. Despite the potential role of metabolism in controlling otolith $\mathrm{Mg}$ and $\mathrm{Mn}$, these two elements can still be used successfully as stock identifiers providing there are substantial differences in elemental concentrations among groups of fish. However, because we used water samples to characterize otolith composition where juveniles were unavailable, we could only use elements and isotopes that accrete in otoliths in proportion to their ambient concentrations. Thus, the lack of a significant relationship between otolith and water composition for both $\mathrm{Mg}: \mathrm{Ca}$ and $\mathrm{Mn}: \mathrm{Ca}$ ratios in this study means predictions could not be made based on water sample analyses for American shad. For this reason, water samples may not be a reliable substitute for direct analyses of otolith composition for studies that require such elements for habitat-specific signatures. We thus caution investigators to not assume water sampling alone can circumvent the necessary step of groundtruthing spatial signature maps with otolith analyses, particularly for elements that do not directly reflect ambient water composition.

Oxygen isotopes proved to be particularly useful for identifying natal origins of American shad. Otoliths from low latitude rivers recorded isotopically heavy ratios, while otoliths from higher latitudes were progressively less enriched in ${ }^{18} \mathrm{O}$. Latitudinal patterns in $\delta^{18} \mathrm{O}$ ratios of precipitation and surface waters are driven by the Rayleigh distillation process and local mean annual temperatures (Dansgaard 1964; Bowen 1988; Kendall and Coplen 2001). The usefulness of $\delta^{18} \mathrm{O}$ ratios for discriminating among rivers was less robust at high latitudes. The slope of the latitudinal cline decreased such that rivers north of the Chesapeake Bay overlap substantially in their $\delta^{18} \mathrm{O}$ ratios. This pattern is not surprising because many of the northern rivers drain catchments in overlapping latitudinal regions (Benke and Cushing 2005). Despite this overlap of northern $\delta^{18} \mathrm{O}$ ratios, oxygen isotopes were the most important factor driving separation of the multivariate signatures along the first canonical variate. The inclusion of $\delta^{18} \mathrm{O}$ ratios therefore contributed substantially to our ability to discriminate among rivers along the large latitudinal gradient surveyed in this study.

Several studies have suggested that $\mathrm{Sr}$ isotopes in otoliths may be powerful tracers of fish movements in freshwater environments (e.g., Kennedy et al. 2002; Barnett-Johnson et al. 2005; McCulloch et al. 2005). The current optimism is based on two observations. First, otolith ${ }^{87} \mathrm{Sr}:{ }^{86} \mathrm{Sr}$ values directly reflect ambient water composition (Kennedy et al. 2000). Second, the geological composition of bedrocks determines the ${ }^{87} \mathrm{Sr}:{ }^{86} \mathrm{Sr}$ ratio of dissolved $\mathrm{Sr}$ in a watershed (Palmer and Edmond 1992). River catchment geology can 
vary over surprisingly small spatial scales, and this in turn generates highly distinctive signatures of individual rivers or streams within a single river watershed (Kennedy et al. 2000). Because the rivers included in this study drained highly heterogeneous surface geologies, river-specific ${ }^{87} \mathrm{Sr}:{ }^{86} \mathrm{Sr}$ ratios were highly variable and an important component of signature separation. Water samples may thus be generally acceptable substitutes for otolith analyses to characterize habitat-specific ${ }^{87} \mathrm{Sr}:{ }^{86} \mathrm{Sr}$ signatures on both small and large geographic scales.

Developments in mass spectrometry have also helped to increase interest in otolith $\mathrm{Sr}$ isotope ratios. Traditional analysis by thermal ionization mass spectrometry (TIMS) requires that otolith material be dissolved and then passed through a cation exchange resin column before making the isotope measurements on a TIMS instrument. Such a method would have been prohibitively time-consuming to analyze the 650 otoliths in this study. In contrast, laser ablation multiple collector ICP-MS provided a method for in situ Sr isotope analyses with no sample requirement beyond the preparation of a sectioned otolith. Moreover, unlike earlier work (Milton and Chenery 2003), the precision of our measurements were similar to that obtained routinely by TIMS.

Data on habitat-specific geochemical signatures are frequently gathered over limited spatial scales (reviewed in Gillanders et al. 2001). While most efforts have examined variability in geochemical signatures on the order of 100$1000 \mathrm{~km}$, a few investigators included samples from geographically distant locations. Collections of adult Atlantic cod (Gadus morhua) otoliths from the east coast of Canada and Iceland were separated by distances of approximately 4000 km (Campana et al. 1994; Campana and Gagné 1995). Proctor et al. (1995) analyzed juvenile southern bluefin tuna (Thunnus maccoyii) otoliths from the coasts of South Africa and Australia, separated by up to $10000 \mathrm{~km}$. Significant differences in elemental signatures in otoliths of northern bluefin tuna (Thunnus thynnus) were detected between the Mediterranean Sea and the western Pacific Ocean, over $14500 \mathrm{~km}$ apart (Secor and Zdanowicz 1998). These investigations assessed large-scale signature variability between widely separated and discrete habitats, analogous to the inclusion of an outgroup in genetic analyses. In contrast, variability in geochemical signatures in otoliths among habitats distributed across a large contiguous range has been rarely examined. Our results confirm that the natal origins of anadromous fishes can be determined over large spatial scales and among multiple populations. Moreover, excellent discrimination was achieved with a total of only four variables that could be recovered from either otolith or water samples.

Attempts to identify natal origins of American shad have been made over several decades using a variety of approaches. Early efforts focused on natural variability in meristic and morphometric characters among rivers (e.g., Warfel and Olsen 1947; Carscadden and Leggett 1975; Melvin et al. 1992). Mitochondrial and microsatellite DNA polymorphisms showed subtle but significant variation among fish from groups of rivers throughout the range of the species (Epifanio et al. 1995; Waters et al. 2000; Nolan et al. 2003), and mtDNA polymorphisms have been used to examine the stock structure of oceanic harvests of American shad
(Brown et al. 1999). However, most efforts have only detected genetic differences among only a few spawning populations or between pooled populations between regions. Only one study examined mtDNA among sufficient numbers of individual populations to allow mixed stock analyses of oceanic harvests (Brown et al. 1996). However, despite large detectable variation at the population level, success rates for assigning individual fish to natal rivers never exceeded $20 \%$ (Brown et al. 1996). A more precise method for determining mixed stock composition of migrating American shad would provide information vital to the effective management of this fully exploited species. Stock abundances are at a fraction of their historic highs (Limburg et al. 2003), with many under moratorium (Olney and Hoenig 2001). While an ocean-intercept fishery is currently closed, any decision to reopen will need to consider the potential mortality that may be exerted on individual stocks. The dynamic and variable marine movements of American shad could be explored effectively by using the groundtruthed database that we have generated to identify natal origins of migrants.

\section{Acknowledgements}

Juveniles samples were provided by N. Gray (Maine Department of Marine Resources), B. Smith (New Hampshire Fish and Game Department), T. Savoy (Connecticut Department of Environmental Protection), K. Hattala (New York State Department of Environmental Conservation), R. Allen (New Jersey Department of Environmental Protection), B. Sadzinski (Maryland Department of Natural Resources), J. Olney (Virginia Institute of Marine Science), P. Kornegay and K. Dockendorf (North Carolina Wildlife Resources Commission), D. Cooke (South Carolina Department of Natural Resources), D. Harrison (Georgia Department of Natural Resources), and R. McBride (Florida Marine Research Institute). Water samples were collected with help from J. FitzGerald, J. Hoffman, and N. Trippel. Thanks go to L. Ball at the Woods Hole Oceanographic Institution (WHOI) Plasma Mass Spectrometry Facility, D. Ostermann at the WHOI Micropaleo Mass Spectrometry Facility, and S. Birdwhistell for help with sample analysis. Sr isotope analyses of water samples were performed by L. Houghton (WHOI). L. Kerr (Marine Biological Laboratory, Woods Hole) provided microscopy facilities for hatchery screening. Oxygen isotope ratios in water samples were analyzed by P. Swart (University of Miami). Statistical assistance was given by V. Starczak. Comments by T. Elsdon and three anonymous reviewers greatly improved the quality of the manuscript. This work was funded by National Science Foundation (NSF) grants OCE-0215905 and OCE-0134998 to SRT and by an American Museum of Natural History Lerner-Gray Grant for Marine Research and a scholarship from SEASPACE, Inc., to BDW.

\section{References}

ASMFC. 2007. American shad stock assessment report for peer review. Atlantic States Marine Fisheries Commission, Bethesda, Md. Stock Assess. Rep. No. 07-01 (Suppl.).

Barnett-Johnson, R., Ramos, F.C., Grimes, C.B., and MacFarlane, R.B. 2005. Validation of $\mathrm{Sr}$ isotopes in otoliths by laser ablation multicollector inductively coupled plasma mass spectrometry (LA-MC-ICPMS): opening avenues in fisheries science applica- 
tions. Can. J. Fish. Aquat. Sci. 62(11): 2425-2430. doi:10.1139/ f05-194.

Bath, G.E., Thorrold, S.R., Jones, C.M., Campana, S.E., McLaren, J.W., and Lam, J.W.H. 2000. Strontium and barium uptake in aragonitic otoliths of marine fish. Geochim. Cosmochim. Acta, 64(10): 1705-1714. doi:10.1016/S0016-7037(99)00419-6.

Benke, A.C., and Cushing, C.C. 2005. Rivers of North America. Elsevier, Burlington, Mass.

Bowen, R. 1988. Isotopes in the earth sciences. Elsevier, New York. Brodziak, J., Bentley, B., Bartley, D., Gall, G.A.E., Gomulkiewicz, R., and Mangel, M. 1992. Tests of genetic stock identification using coded wire tagged fish. Can. J. Fish. Aquat. Sci. 49(7): 1507-1517. doi:10.1139/f92-167.

Brown, B.L., Epifanio, J.M., Smouse, P.E., and Kobak, C.J. 1996. Temporal stability of mtDNA haplotype frequencies in American shad stocks: to pool or not to pool across years? Can. J. Fish. Aquat. Sci. 53(10): 2274-2283. doi:10.1139/cjfas-53-10-2274.

Brown, B.L., Smouse, P.E., Epifanio, J.M., and Kobak, C.J. 1999. Mitochondrial DNA mixed-stock analysis of American shad: coastal harvests are dynamic and variable. Trans. Am. Fish. Soc. 128(6): 977-994. doi:10.1577/1548-8659(1999) 128<0977:MDMSAO>2.0.CO;2.

Campana, S.E. 1999. Chemistry and composition of fish otoliths: pathways, mechanisms and applications. Mar. Ecol. Prog. Ser. 188: 263-297. doi:10.3354/meps 188263.

Campana, S.E., and Gagné, J.A. 1995. Cod stock discrimination using ICPMS elemental assays of otoliths. In Recent developments in fish otolith research. Edited by D.H. Secor, J.M. Dean, and S.E. Campana. University of South Carolina Press, Columbia, S.C. pp. 671-691.

Campana, S.E., and Nielson, J.D. 1985. Microstructure of fish otoliths. Can. J. Fish. Aquat. Sci. 42(5): 1014-1032. doi:10.1139/ f85-127.

Campana, S.E., and Thorrold, S.R. 2001. Otoliths, increments, and elements: keys to a comprehensive understanding of fish populations? Can. J. Fish. Aquat. Sci. 58(1): 30-38. doi:10.1139/cjfas58-1-30.

Campana, S.E., Fowler, A.J., and Jones, C.M. 1994. Otolith elemental fingerprinting for stock identification of Atlantic cod (Gadus morhua) using laser ablation ICPMS. Can. J. Fish. Aquat. Sci. 51(9): 1942-1950. doi:10.1139/f94-196.

Carscadden, J.E., and Leggett, W.C. 1975. Meristic differences in spawning populations of American shad, Alosa sapidissima: evidence for homing to tributaries in the St. John River, New Brunswick. J. Fish. Res. Board Can. 32(5): 653660.

Dadswell, M.J., Melvin, G.D., Williams, P.J., and Themelis, D.E. 1987. Influences of origin, life history, and chance on the Atlantic coast migration of American shad. Am. Fish. Soc. Symp. 1: 313-330.

Dansgaard, W. 1964. Stable isotopes in precipitation. Tellus, 16(4): 436-438.

Devore, J.L. 2004. Probability and statistics for engineering and the sciences. Brooks/Cole - Thomson Learning, Belmont, Calif.

Elsdon, T.S., and Gillanders, B.M. 2003. Relationship between water and otolith elemental concentrations in juvenile black bream Acanthopagrus butcheri. Mar. Ecol. Prog. Ser. 260: 263272. doi:10.3354/meps260263.

Epifanio, J.M., Smouse, P.E., Kobak, C.J., and Brown, B.L. 1995. Mitochondrial DNA divergence among populations of American shad (Alosa sapidissima): how much variation is enough for mixed-stock analysis? Can. J. Fish. Aquat. Sci. 52(8): 16881702. doi:10.1139/f95-761.

Epstein, S., and Mayeda, T. 1953. Variation of ${ }^{18} \mathrm{O}$ content of water from natural sources. Geochim. Cosmochim. Acta, 4(5): 213-224. doi:10.1016/0016-7037(53)90051-9.

Gillanders, B.M., Sanchez-Jerez, P., Bayle-Sempere, J., and Ramos-Espla, A. 2001. Trace elements in otoliths of the twobranded bream from a coastal region in the south-west Mediterranean: are there differences among locations? J. Fish Biol. 59(2): 350-363. doi:10.1111/j.1095-8649.2001.tb00135.x.

Jackson, M.G., and Hart, S.R. 2006. Strontium isotopes in melt inclusions from Samoan basalts: implications for heterogeneity in the Samoan plume. Earth Planet. Sci. Lett. 245(1-2): 260277. doi:10.1016/j.epsl.2006.02.040.

Kendall, C., and Coplen, T.B. 2001. Distribution of oxygen-18 and deuterium in river waters across the United States. Hydrol. Process. 15(7): 1363-1393. doi:10.1002/hyp.217.

Kennedy, B.P., Folt, C.L., Blum, J.D., and Chamberlain, C.P. 1997. Natural isotope markers in salmon. Nature (London), 387(6635): 766-767. doi:10.1038/42835.

Kennedy, B.P., Blum, J.D., Folt, C.L., and Nislow, K.H. 2000. Using natural strontium isotopic signatures as fish markers: methodology and application. Can. J. Fish. Aquat. Sci. 57(11): 2280-2292. doi:10.1139/cjfas-57-11-2280.

Kennedy, B.P., Klaue, A., Blum, J.D., Folt, C.L., and Nislow, K.H. 2002. Reconstructing the lives of fish using $\mathrm{Sr}$ isotopes in otoliths. Can. J. Fish. Aquat. Sci. 59(6): 925-929. doi:10. 1139/f02-070.

Kraus, R.T., and Secor, D.H. 2004. Incorporation of strontium into otoliths of an estuarine fish. J. Exp. Mar. Biol. Ecol. 302(1): 85106. doi:10.1016/j.jembe.2003.10.004.

Lehman, N., and Joyce, G.F. 1993. Evolution in vitro of an RNA enzyme with altered metal dependence. Nature (London), 361(6408): 182-185. doi:10.1038/361182a0. PMID:8421526.

Limburg, K.E., Hattala, K.A., and Kahnle, A. 2003. American shad in its native range. Am. Fish. Soc. Symp. 35: 125-140.

Maki, K.L., Hoenig, J.M., and Olney, J.E. 2001. Estimating proportion mature at age when immature fish are unavailable for study, with application to American shad in the York River, Virginia. N. Am. J. Fish. Manage. 21(4): 703-716. doi:10.1577/15488675(2001)021<0703:EPMAAW>2.0.CO;2.

McCulloch, M., Cappo, M., Aumend, J., and Müller, W. 2005. Tracing the life history of individual barramundi using laser ablation MC-ICP-MS Sr-isotopic and $\mathrm{Sr} / \mathrm{Ba}$ ratios in otoliths. Mar. Freshw. Res. 56(5): 637-644. doi:10.1071/MF04184.

McDowall, R.M. 2003. Shads and diadromy: implications for ecology, evolution, and biogeography. Am. Fish. Soc. Symp. 35: 11-23.

Melvin, G.D., Dadswell, M.J., and McKenzie, J.A. 1992. Usefulness of meristic and morphometric characters in discriminating populations of American shad (Alosa sapidissima) (Osteichthyes:Clupeidae) inhabiting a marine environment. Can. J. Fish. Aquat. Sci. 49(2): 266-280. doi:10.1139/f92-031.

Metcalfe, J.D., Arnold, G., and McDowall, R. 2002. Migration. In Handbook of fish biology and fisheries, Vol. 1. Edited by P.J.B. Hart and J.D. Reynolds. Blackwell Scientific, Oxford, UK. pp. 175-199.

Milton, D.A., and Chenery, S.R. 2003. Movement patterns of the tropical shad hilsa (Tenualosa ilisha) inferred from transects of ${ }^{87} \mathrm{Sr} /{ }^{86} \mathrm{Sr}$ isotope ratios in their otoliths. Can. J. Fish. Aquat. Sci. 60(11): 1376-1385. doi:10.1139/f03-133.

Nolan, K.A., Waldman, J.R., and Wirgin, I. 2003. Intraspecific and interspecific molecular differentiation of American shad and Alabama shad: a synthesis. Am. Fish. Soc. Symp. 35: 295-302.

Olney, J.E., and Hoenig, J.M. 2001. Managing a fishery under moratorium: assessment opportunities for Virginia's stocks of American shad (Alosa sapidissima). Fisheries, 26(2): 6-12. doi:10.1577/1548-8446(2001)026<0006:MAFUMA>2.0.CO;2. 
Ostermann, D.R., and Curry, W.B. 2000. Calibration of stable isotopic data: an enriched $\delta^{18} \mathrm{O}$ standard used for source gas mixing detection and correction. Paleoceanography, 15(3): 353-360. doi:10.1029/1999PA000411.

Palmer, M.R., and Edmond, J.M. 1992. Controls over the strontium isotope composition of river water. Geochim. Cosmochim. Acta, 56(5): 2099-2111. doi:10.1016/0016-7037(92)90332-D.

Proctor, C.H., Thresher, R.E., Gunn, J.S., Mills, D.J., Harrowfield, I.R., and Sie, S.H. 1995. Stock structure of the southern bluefin tuna Thunnus maccoyii: an investigation based on probe microanalysis of otolith composition. Mar. Biol. (Berlin), 122(4): 511-526. doi:10.1007/BF00350674.

Quinn, T.P., and Leggett, W.C. 1987. Perspectives on the marine migrations of diadromous fishes. Am. Fish. Soc. Symp. 1: 377-388.

Rainbow, P.S. 1997. Trace metal accumulation in marine invertebrates: marine biology or marine chemistry? J. Mar. Biol. Assoc. U.K. 77(1): 195-210.

Rosenthal, Y., Field, P.M., and Sherrell, R.M. 1999. Precise determination of element/calcium ratios in calcareous samples using sector field inductively coupled plasma mass spectrometry. Anal. Chem. 71(15): 3248-3253. doi:10.1021/ac981410x.

Secor, D.H., and Zdanowicz, V.S. 1998. Otolith microconstituent analysis of juvenile bluefin tuna (Thunnus thynnus) from the Mediterranean Sea and Pacific Ocean. Fish. Res. 36(2-3): 251256. doi:10.1016/S0165-7836(98)00103-9.

Sturgeon, R.E., Willie, S.N., Yang, L., Greenberg, R., Spatz, R.O., Chen, Z., Scriver, C., Clancy, V., Lam, J.W., and Thorrold, S. 2005. Certification of a fish otolith reference material in support of quality assurance for trace element analysis. J. Anal. At. Spectrom. 20(10): 1067-1071. doi:10.1039/b503655k.

Swart, P.K., and Price, R. 2002. Origin of salinity variations in Florida Bay. Limnol. Oceanogr. 47(4): 1234-1241.
Thorrold, S.R., Jones, C.M., Campana, S.E., McLaren, J.W., and Lam, J.W.H. 1998. Trace element signatures in otoliths record natal river of juvenile American shad (Alosa sapidissima). Limnol. Oceanogr. 43(8): 1826-1835.

Thorrold, S.R., Latkoczy, C., Swart, P.K., and Jones, C.M. 2001. Natal homing in a marine fish metapopulation. Science (Washington, D.C.), 291(5502): 297-299. doi:10.1126/science. 291.5502.297. PMID:11209078.

Thorrold, S.R., Jones, G.P., Hellberg, M.E., Burton, R.S., Swearer, S.E., Neigel, J.E., Morgan, S.G., and Warner, R.R. 2002. Quantifying larval retention and connectivity in marine populations with artificial and natural markers. Bull. Mar. Sci. 70(1): 291-308.

Walther, B.D., and Thorrold, S.R. 2006. Water, not food, contributes the majority of strontium and barium deposited in the otoliths of a marine fish. Mar. Ecol. Prog. Ser. 311: 125-130. doi:10.3354/meps311125.

Walther, B.D., Thorrold, S.R., and Olney, J.E. 2008. Geochemical signatures in otoliths record natal origins of American shad. Trans. Am. Fish. Soc. 137(1): 57-69. doi:10.1577/T07-029.1.

Warfel, H.E., and Olsen, Y.H. 1947. Vertebral counts and the problem of races in the Atlantic shad. Copeia, 1947(3): 177183. doi: $10.2307 / 1438846$.

Waters, J.M., Epifanio, J.M., Gunter, T., and Brown, B.L. 2000. Homing behaviour facilitates subtle genetic differentiation among river populations of Alosa sapidissima: microsatellites and mtDNA. J. Fish Biol. 56(3): 622-636. doi:10.1111/j. 1095-8649.2000.tb00760.x.

Yoshinaga, J., Nakama, A., Morita, M., and Edmonds, J.S. 2000. Fish otolith reference material for quality assurance of chemical analyses. Mar. Chem. 69(1-2): 91-97. doi:10.1016/ S0304-4203(99)00098-5. 